\title{
Influence of Parental Expectations and Involvement on the Learning Outcomes of Children with Special Educational Needs in Tamale
}

\author{
Issaka Cecilia Alimatu ${ }^{1, *}$, Isaac Nyame ${ }^{1}$, Fatima Iddrisu $\mathrm{Abu}^{2}$ \\ ${ }^{1}$ Faculty of Education, University for Development Studies, Ghana \\ ${ }^{2}$ Department of Languages and Liberal Studies, Tamale Technical University, Ghana
}

Received April 29, 2021; Revised June 17, 2021; Accepted July 19, 2021

\begin{abstract}
Cite This Paper in the following Citation Styles
(a): [1] Issaka Cecilia Alimatu, Isaac Nyame, Fatima Iddrisu Abu, "Influence of Parental Expectations and Involvement on the Learning Outcomes of Children with Special Educational Needs in Tamale, "Universal Journal of Educational Research, Vol. 9, No. 8, pp. 1544 - 1551, 2021. DOI: 10.13189/ujer.2021.090806.
\end{abstract}

(b): Issaka Cecilia Alimatu, Isaac Nyame, Fatima Iddrisu Abu (2021). Influence of Parental Expectations and Involvement on the Learning Outcomes of Children with Special Educational Needs in Tamale. Universal Journal of Educational Research, 9(8), 1544 - 1551. DOI: 10.13189/ujer.2021.090806.

Copyright $\bigcirc 2021$ by authors, all rights reserved. Authors agree that this article remains permanently open access under the terms of the Creative Commons Attribution License 4.0 International License

\begin{abstract}
The aim of this study was to investigate the influence of parental expectations and their involvement on the learning outcomes of students with special educational needs and disabilities in the Tamale Metropolis. The study was a quantitative survey. Parents of students with special needs formed the population of the study. A total of 50 participants were sampled through snowballing. These parents had various levels of education from basic to tertiary levels. Questionnaire was the main instrument for data collection. The data were obtained personally by the researchers after they had made personal contacts with the parents. The data obtained were analysed in SPSS. Frequency distribution tables and percentages were used for analysing the descriptive data while the hypotheses were tested using multiple regression and Spearman Browns' correlation coefficient. It was revealed that parents had high expectations from the school and teachers concerning the education of children with special needs and disabilities. They were also actively involved in the education of their children however; a number of factors such as family health issues, transportation and language barriers influenced their involvement in the education of their children with special needs. A multiple regression was run to predict learning outcomes from parental expectations and their involvement. The two variables combined to show a statistical significant prediction of learning outcomes, $\mathrm{F}(2,47)=24.427, \mathrm{p}(.000)<.0005$,
\end{abstract}

$\mathrm{R} 2=.510$. However, only parental involvement added statistically significantly to the prediction, $\mathrm{p}<.05$.

Keywords Parental Expectations, Parental Involvement, Learning Outcomes, Children with Disabilities and Special Education Needs

\section{Introduction}

All children, including those with disabilities and special educational needs, have the right to an education. This has been entrenched in the United Nations Declaration on Human Rights [2]. The United Nations Declaration on Human Rights emphasizes the importance of education in developing respect for human rights and fundamental freedoms (Emmert, 2021). Several international and national policies and laws acknowledge this right hence governments all over the world have improved efforts to uphold the right to education. In Ghana for example, the 1992 constitution, 2006 Persons with Disabilities Act (Act 715), and the Education Act of 2008 among others make provision for the universal basic education for all children regardless of their differences.

It is widely accepted that the socioeconomic development of every nation greatly depends on education 
which harnesses and trains the human resource potentials for the various sectors of the economy. This is true for all individuals including marginalized groups such as those with disabilities. Though education for marginalized groups continues to embattle several challenges, there is no denying fact that access to education has improved for marginalized groups including those with special educational needs and disabilities.

For this reason, the family which remains the building blocks and the microcosm of the larger society has a greater responsibility in ensuring improved access, participation and achievement of their children with special educational needs in schools. Evidence from literature suggests among other factors that parental expectations and involvement hold greater value towards the educational attainment of their children in school $[13,18,27]$. Parental expectation is conceptualized as the anticipation that parents have for their children to successfully progress in school work [33]. It is evident from literature that parental expectations play a major role in children's academic success $[5,10,15]$. Students with high expectations from their parents show better academic performance, and they are likely to stay in school longer than students whose parents have low expectations for them [10].

It is well recognized in educational literature that parental expectations play a significant role in shaping young people's academic outcomes $[5,10,15]$. In turn, academic outcomes affect future employment and earnings. To date, much of the research on parental expectations has focused on parents of children from marginalized groups such as ethnic minorities or disadvantaged backgrounds [5,30] while less is known about the expectations of parents of children with disabilities and how these expectations impact on student outcomes [3]. Meanwhile, it has been reported that the social and academic outcomes of children with special needs and disabilities are lower than their peers without special needs particularly in relation to their academic test scores $[6,15,35]$. Research in this area has shown that the expectations that parents hold for their children influence children's actual academic outcomes [16].

Concerning the factors influencing parental expectations, the composition of the household, the home climate, and the level of education of the parents themselves have been implicated [3]. Differences in parenting behaviours, parents' ability to participate with their child's school or academics, and parents' accuracy in rating their child's aptitude have all been connected to parental education [29,33]. Some studies [9,31] specifically look at how parental expectations affect academic achievements of children with impairments and special educational needs. The type of condition has also been proven to influence parents' expectations of their children's education. Parents' expectations have further been shown to be influenced by the type of disability, with parents of children with specific learning disorders being more likely to have higher expectations than parents of children with more severe learning impairments [25].

Related to parental expectations is their involvement. Afolabi [1] argued that parental involvement is a key method for implementing inclusive education effectively, and it is especially important for children with special needs and disabilities. Parental involvement can be conceptualized as the collaborative engagement between parents and the school about every aspect of the child's education and development for which the school and the home are responsible. When parents are more involved and empowered in the educational process, students' learning outcomes improve [34]. This emphasizes the need for parent-teacher partnership in supporting the learning needs of all students, including those with various impairments [13]. Spann [26] discovered that parental involvement is important because it leads to better generalization and preservation of treatment gains, greater continuity in intervention programs, higher levels of parent satisfaction, and more effective problem-solving procedures. Buchori [7] claims that education will fail if parents do not participate. Giving full attention to the child's growth as a person, rather than just what the child has accomplished, is one of the primary criteria parents must meet in order to seek effective cooperation with the school for optimizing the educational process.

Every educational process requires the cooperation between the school and the parents [4]. Parents play important roles in educating and supporting learners with special educational needs [20]. This is partly due to the rights they enjoy and the responsibilities they bear as parents. Not only these but they are also sources of information, partners in designing and implementing programmes for their children, and 'consumers' of the education their children receive. Parents' involvement in education accordingly leads to improvement and provides parents with a number of communication opportunities [4]. Clough and Nutbrown [8] also stated that parents should be included in the school since they require information about the school's methods, structure, and intervention. Bariroh [4] emphasized the need for parental involvement and recommended that parents should be more intensive in assisting, accompanying, and guiding their children who have special needs so that their motivation and academic achievement can be enhanced. Teachers and schools should give more fruitful collaboration between schools and the parents to meet children's needs and potentials.

Parental participation in education decision-making process is vitally important. Studies have shown that parents' involvement in the education of their children with disabilities promote holistic development of the child [11]. Logsdon [17] asserted that parents provide critical input and as guardians, they know their children better than anyone else and have the most complete 
understanding of a child's physical, social, developmental and family history. Parents are the only adults in the educational process who have been and will continue to be deeply involved throughout the child's education; while they may not be educators themselves, they bring years of experience in other professions and aspects of life to the process. Thus, while some parents may be teachers, others may not even work in the education fraternity. Notwithstanding, whatever their professions may be, parents can bring experiences from different professional domains to bear regarding their children's education.

Despite the greater emphasis on parental expectations and involvement on the educational outcomes of children in general and those with special educational needs in particular reported in several international literature, it appears parental involvement needs much attention both in principle and in practice especially for children with special educational needs. In the northern part of Ghana where there is still widespread primitive and superstitious belief about disabilities, parents comfortably find schools either special or regular as "dumping sites" for their children with special educational needs and disabilities. It is therefore uncommon to find that some parents if they will look for admission at all for their special needs children apparently have no business to do with the schools and how their children succeed or fail in the schools are none of their business. Other parents probably for fear of stigmatization do not even want to secure admissions for such children and on most occasions some benevolent individuals within and outside the family enrol such children in school. It is common to find some disable children roaming on the streets without the necessary skills to live independent lives. Many parents do not have understanding and skills needed to engage their wards to continue to learn at home. Inherent in this challenge is that many parents hold very low expectations for such children and consider any investment in their education as a waste of time and resources.

For children who have the opportunity to be in school, it is essential to consider how parental expectations of their children's education and their involvement affect their learning outcomes in the schools. Parental Involvement may among other things be related to belief in the knowledge, skills and effectiveness in organizing learning aids, and with the expectations towards the child's learning (19). To build relationships with children who may have impairments and need for specialised instruction, there is a need to intensify hostile-coercive and supportive-engaged attitudes $(22,23)$. However, Roth and Salikutluk [28] argued that research on parental expectations of the learning outcomes of special needs children and their involvement remains limited despite their substantial impact on the educational outcomes and success of their children. This article therefore explored parents' perception of their expectations and involvement on the educational outcomes of children who have special educational needs or disabilities in inclusive and special schools in Tamale.

\section{Aims of the Research}

The aim of this study was to explore parental expectations and involvement in the education of children with disabilities in the Northern Region of Ghana. Specifically, the study sought to:

1. Explore the expectations of parents in the education of their children with any form of disabilities in Northern Region of Ghana.

2. Find out the extent to which parents of children with special needs are involved in the education of their children.

3. To find out the impact of parental expectations and involvement on the learning outcomes of children with special needs.

4. Identify the factors affecting parental involvement in the education of their children with special educational needs and disabilities.

\section{Research Questions}

The study was guided by the following questions:

1. What are the expectations of parents in educating their children with disabilities?

2. To what extent are parents of children with special needs and disabilities involved in the education of their children?

3. What are the factors affecting parental involvement in the education of their children with special educational needs and disabilities?

Hypotheses

1. There is no statistically significant relationship between parental expectations and their involvement.

2. There is no statistically significant relationship between parental expectations and involvement, and the learning outcomes of learners with special needs and disabilities.

\section{Methodology}

The goal of this study was to find out how parents' expectations of their children's education and their involvement influenced the learning outcomes of children with special educational needs. This research was based on a quantitative survey. In quantitative survey, data is collected from a group of individuals by asking them to answer questions on a questionnaire [8]. The survey was employed because the researchers wanted to recruit a larger number of people to be part of the study in order to create generalizable results. The study population was the 
parents of children with disabilities and special educational needs in the Tamale Metropolis. A research population refers to the individuals who possess the characteristics of interest which qualifies them to be part of a study [12]. A total of 50 parents were sampled using snowball technique. In snowball sampling researchers identify a small number of individuals who have the characteristics of interest and recruit them. These initial recruits are then used as informants to identify others who qualify for inclusion and these, in turn, identify yet others [10]. This method is useful for sampling hard-to-reach population where access is difficult [14]. Though parents of children with disabilities are not uncommon, the stigma associated a disability or special educational need condition makes it difficult for parents to openly accept that they have a child with a disability.

In using snowball to get the sample for this research, the researchers first identified few parents who had children with one form of disability or the other and recruited them. These initial recruits linked the researchers to other parents who had children with varied conditions such as visual impairment, hearing impairment, intellectual disabilities, autism, communication and behavioral problems as well as multiple handicaps attending basic schools either special or regular schools. In Ghana, basic education entails preschool up to the junior high school level with the average age of pupils and students between 4 to 14 years. Parental survey questionnaire was developed to cover parental expectations, involvement and learning outcomes of their children's education. Also included in the questionnaire were items soliciting information about factors influencing parental involvement. To determine the relationship between parental expectations and involvement, as well as the combined impact of parental expectations and involvement on the learning outcomes of learners with special education needs, two hypotheses were tested. The demographic data of the participants included parents' sex, their level of education, the type of disability of their children, and the type of school their children attended. The data was analyzed using frequency distribution tables and percentages, multiple regression analysis, and Spearman Brown's correlation.

\section{Results}

Three main research questions and two hypotheses were raised to guide the conduct of this study. The data from the research questions were analysed using frequency distribution tables and percentages with their means and standard deviations being reported. Responses to items on parental expectations, their involvement, and factors affecting parental involvement were rated on a five-point Likert scale of Strongly Disagree (SD); Disagree (D); Agree (A); Strongly Agree (SA); and Neutral (N). For the purpose of easy presentation and analysis SD and D were combined as Disagree and SA and A were considered Agree with Neutral remaining on its own as shown in the Tables.

It is evident from Table 1 that, the parents' responses showed that they considered all the factors raised as their expectations of teachers and the school with high means and low standard deviations. The sum of means was 36.84 with an average mean of 4.09 above the average of 3 . Similarly the sum of Standard Deviations was 10.03 with average Standard Deviation of 1.11.

Table 1. Parental Expectations in the education of their children with special needs

\begin{tabular}{|c|c|c|c|c|c|c|}
\hline S/no. & Parental expectations & $\mathrm{D}(\mathrm{F}, \%)$ & $\mathrm{A}(\mathrm{F}, \%)$ & $\mathrm{N}(\mathrm{F}, \%)$ & MEAN & ST.DEV \\
\hline 1. & $\begin{array}{l}\text { Teachers should encourage children with special } \\
\text { needs and disabilities to learn }\end{array}$ & $3(6)$ & $43(86)$ & $4(8)$ & 4.22 & .91 \\
\hline 2. & $\begin{array}{l}\text { Teachers should provide extra help for children with } \\
\text { special needs }\end{array}$ & $10(20)$ & $39(78)$ & $1(2)$ & 3.92 & 1.43 \\
\hline 3. & $\begin{array}{l}\text { Teachers should have high expectations of children } \\
\text { with special needs }\end{array}$ & $4(8)$ & $46(92)$ & & 4.30 & 1.09 \\
\hline 4. & $\begin{array}{l}\text { The classroom environment should be structured to } \\
\text { suit children with special needs }\end{array}$ & $4(8)$ & $46(92)$ & & 4.32 & 1.09 \\
\hline 5. & $\begin{array}{l}\text { Teachers should know about and appreciate children } \\
\text { with special needs in their classrooms }\end{array}$ & $6(12)$ & $42(84)$ & $2(4)$ & 4.10 & 1.23 \\
\hline 6. & $\begin{array}{l}\text { Teachers should care about a child with special needs } \\
\text { as an individual }\end{array}$ & $3(6)$ & $46(92)$ & $1(2)$ & 4.20 & .90 \\
\hline 7. & $\begin{array}{l}\text { Teachers should help a child with special needs feel } \\
\text { good about him/herself }\end{array}$ & $6(12)$ & $44(88)$ & & 4.14 & 1.21 \\
\hline 8. & $\begin{array}{l}\text { Teachers should contact parents of a child with } \\
\text { special needs when the need arises }\end{array}$ & $6(12)$ & $41(82)$ & $3(6)$ & 3.98 & 1.15 \\
\hline 9. & $\begin{array}{l}\text { Parent-teacher conferences are important in meeting } \\
\text { the learning needs of children with special needs }\end{array}$ & $7(14)$ & $33(66)$ & $10(20)$ & 3.66 & 1.02 \\
\hline
\end{tabular}

Sum of means $=36.84 ;$ Average of means $=4.09 ;$ Sum of $\mathrm{SD}=10.03 ;$ Average of $=1.11$ 
Table 2. Parental Involvement in the education of children with special needs

\begin{tabular}{|c|c|c|c|c|c|c|}
\hline S/no. & Parental involvement & $\mathrm{D}(\mathrm{F}, \%)$ & $\mathrm{A}(\mathrm{F}, \%)$ & $\mathbf{N}(\mathbf{F}, \%)$ & MEAN & ST.DEV \\
\hline 1. & My child's teacher contacts me when necessary & $9(18)$ & $35(70)$ & $6(12)$ & 3.70 & 1.09 \\
\hline 2. & $\begin{array}{l}\text { I could help my child more if the teacher gave me } \\
\text { ideas }\end{array}$ & $22(44)$ & $21(42)$ & $7(14)$ & 3.06 & 1.17 \\
\hline 3. & $\begin{array}{l}\text { My child's teacher views me as an important partner } \\
\text { in my child's education }\end{array}$ & $7(14)$ & $35(70)$ & $8(16)$ & 3.66 & 1.09 \\
\hline 4. & My child's teacher returns my phone calls promptly & $10(20)$ & $32(64)$ & $8(16)$ & 3.62 & 1.23 \\
\hline 5. & I feel I am actively involved in my child's education & $8(16)$ & $31(62)$ & $11(22)$ & 3.72 & 1.03 \\
\hline 6. & $\begin{array}{l}\text { When I try to be involved, I don't feel my efforts are } \\
\text { appreciated }\end{array}$ & $40(80)$ & $3(6)$ & $7(14)$ & 3.94 & .91 \\
\hline 7. & $\begin{array}{l}\text { My child's teacher invites me to visit the classroom } \\
\text { when necessary }\end{array}$ & $4(8)$ & $40(80)$ & $6(12)$ & 3.94 & .96 \\
\hline 8. & I visit my child's classroom occasionally & $4(8)$ & $42(84)$ & $4(8)$ & 4.06 & 1.09 \\
\hline 9. & I attend parent-teacher conferences most of the time & $4(8)$ & $44(88)$ & $2(4)$ & 4.08 & .94 \\
\hline 10. & I motivate my child with disability a lot & $5(10)$ & $44(88)$ & $1(2)$ & 4.00 & .88 \\
\hline 11. & I support my child with disability in his school work & $3(6)$ & $43(86)$ & $4(8)$ & 4.10 & .93 \\
\hline 12. & $\begin{array}{l}\text { I am ready to carry out assigned responsibilities by } \\
\text { the teacher }\end{array}$ & $2(4)$ & 47 (94) & $1(2)$ & 4.16 & .81 \\
\hline
\end{tabular}

Sum of means $=46.04 ;$ Average of means $=3.84 ;$ Sum of $\mathrm{SD}=12.13 ;$ Average of $=1.01$

Table 3. Factors affecting Parental Involvement

\begin{tabular}{|c|c|c|c|c|c|c|}
\hline S/no. & Factors affecting Parental Involvement & $\mathrm{D}(\mathrm{F}, \%)$ & $\mathrm{A}(\mathrm{F}, \%)$ & $\mathbf{N}(\mathbf{F}, \%)$ & MEAN & ST.DEV \\
\hline 1. & Lack of transportation reduces my involvement & $5(10)$ & $43(86)$ & 2(4) & 4.06 & 1.17 \\
\hline 2. & Family health problems reduce my involvement & $5(10)$ & $43(86)$ & 2(4) & 4.16 & 1.20 \\
\hline 3. & $\begin{array}{l}\text { My work schedule makes it hard for me to be } \\
\text { involved }\end{array}$ & $7(14)$ & $40(80)$ & $3(6)$ & 3.86 & 1.25 \\
\hline 4. & $\begin{array}{l}\text { Teachers' attitude towards my child frustrate my } \\
\text { involvement }\end{array}$ & $9(18)$ & $26(52)$ & $15(30)$ & 4.06 & 1.36 \\
\hline 5. & $\begin{array}{l}\text { Teachers do not have time to engage with parents on } \\
\text { their children's schooling }\end{array}$ & $6(12)$ & $40(80)$ & $4(8)$ & 3.92 & 1.14 \\
\hline 6. & $\begin{array}{l}\text { Teachers have low expectations of what children } \\
\text { with disabilities can do }\end{array}$ & $5(10)$ & $29(58)$ & $16(32)$ & 4.28 & 1.19 \\
\hline 7. & $\begin{array}{l}\text { The school atmosphere prevents parental } \\
\text { involvement }\end{array}$ & $4(8)$ & $46(92)$ & & 4.08 & 1.03 \\
\hline 8. & $\begin{array}{l}\text { Difficulty in expressing myself in English reduces } \\
\text { my involvement }\end{array}$ & $6(12)$ & $44(88)$ & & 4.14 & 1.21 \\
\hline 9. & $\begin{array}{l}\text { Lack of available care for my child reduces my } \\
\text { involvement }\end{array}$ & $3(6)$ & 47 (94) & & 4.32 & .91 \\
\hline
\end{tabular}

Sum of means $=36.88 ;$ Average of means $=4.09 ;$ Sum of $\mathrm{SD}=10.46 ;$ Average of $=1.16$

From Table 2, it is evident from the parents' responses that they considered all the factors raised as their expectations of teachers and the school with high means and low standard deviations. The sum of means was 36.84 with an average mean of 4.09 above the average of 3 . Similarly the sum of Standard Deviations was 10.03 with average Standard Deviation of 1.11. Thus, it can be concluded that the parents were involved in the education of their children with special needs.

It can be seen from Table 3 that, the parents' responses showed that they considered all the factors raised as affecting their involvement with high means and low standard deviations. The sum of means was 36.88 with an average mean of 4.09 above the average of 3. Similarly the sum of Standard Deviations was 10.46 with average Standard Deviation of 1.16. These mean that the factors affecting parental involvement in the education of their children with special needs either in special or regular schools included lack of transportation, family health problems, work schedules, teachers' attitudes, inadequate time for teachers to engage with parents, low expectations on the part of teachers, poor school atmosphere, difficulty in expressing themselves in English language and lack of care for children with special needs in schools.

\section{Results of the Hypotheses}

To find the impact of parental expectations and involvement on the learning outcomes of children with special needs, a multiple regression analysis was run in SPSS. 
Model Summary

\begin{tabular}{cccccc}
\hline Model & $\mathrm{R}$ & $\mathrm{R}$ Square & Adjusted R Square & Std. Error of the Estimate & Durbin-Watson \\
\hline 1 & $.714^{\mathrm{a}}$ & .510 & .489 & .53348 & 1.708 \\
\hline
\end{tabular}

a) Predictors: (Constant), Parental Involvement, Parental Expectations

b) Dependent Variable: Learning Outcomes

\begin{tabular}{ccccccc}
\hline \multicolumn{1}{c}{ ANOVA $^{\mathbf{a}}$} \\
\hline Model & Sum of Squares & Df & Mean Square & F & Sig. \\
\hline \multirow{2}{*}{1} & Regression & 13.904 & 2 & 6.952 & 24.427 & $.000^{\mathrm{b}}$ \\
& Residual & 13.376 & 47 & .285 & & \\
\hline
\end{tabular}

a) Dependent Variable: Learning Outcomes

b) Predictors: (Constant), Parental Involvement, Parental Expectations

\begin{tabular}{|c|c|c|c|c|c|c|c|c|}
\hline \multicolumn{9}{|c|}{ Coefficients $^{\mathrm{a}}$} \\
\hline \multicolumn{2}{|r|}{ Model } & \multicolumn{2}{|c|}{ Unstandardized Coefficients } & \multirow{2}{*}{$\begin{array}{c}\begin{array}{c}\text { Standardized } \\
\text { Coefficients }\end{array} \\
\text { Beta }\end{array}$} & \multirow[t]{2}{*}{$\mathbf{T}$} & \multirow[t]{2}{*}{ Sig. } & \multicolumn{2}{|c|}{$\begin{array}{l}95.0 \% \text { Confidence Interval } \\
\text { for B }\end{array}$} \\
\hline & & B & Std. Error & & & & Lower Bou & per Bound \\
\hline \multirow{3}{*}{1} & (Constant) & 1.814 & .493 & & 3.682 & .001 & .823 & 2.806 \\
\hline & $\begin{array}{c}\text { Parental } \\
\text { Expectations (PE) }\end{array}$ & -.046 & .079 & -.059 & -.582 & .563 & -.206 & .114 \\
\hline & $\begin{array}{c}\text { Parental } \\
\text { Involvement (PI) }\end{array}$ & .628 & .090 & .714 & 6.984 & .000 & .447 & .809 \\
\hline
\end{tabular}

a. Dependent Variable: Learning Outcomes $=1.814-(.046 \times \mathrm{PE})+(0.628 \times \mathrm{PI})$

The correlation coefficient $\mathrm{R}$ value 0.714 showed a good prediction of the dependent variable by the independent variables. The coefficient of determination $\mathrm{R}$ square value of 0.510 showed that the independent variables accounted for $51.1 \%$ of variability in the dependent variable.

In determining whether the model was a good fit for the data, the ANOVA table showed that the independent variables statistically significantly predicted the dependent variable, $\mathrm{F}(2,47)=24.427, p(.000)<.0005$ which showed that the regression model was a good fit for the data.

From the coefficients table, it is shown that parental expectations showed a negative relationship with learning outcomes as the Beta value for parental expectations was -.046. This shows that for each additional increase in parental expectations, there is .046 decrease in children's learning outcomes. However, parental involvement accounted for .628 in the dependent variable. This means that any additional levels of parental involvement lead to .628 increase in learning outcomes.

On the test of statistical significance, the p-value of parental expectations was different from 0 (.563) showing that it was not statistically significant whereas the $p$-value of parental involvement was not different from $0(.000)$ showing statistical significance.

Further correlation analysis showed no statistically significant relationship between parental education and their involvement $(\mathrm{r}=.129)$ as well as their expectations (-.059) in their children's education. Likewise the type of disability of the child did not show any statistically significant relationship with parental expectations $(\mathrm{r}=$ $-.140)$ and their involvement $(\mathrm{r}=-.128)$. More so, the type of school a child with special need attended did not show any statistically significant relationship with parental expectations $(r=.062)$ and their involvement $(r=-.180)$. Finally, there was no statistically significant relationship between the sex of parents and their expectations $(r=$ $-.125)$ and their involvement $(\mathrm{r}=-.115)$.

\section{Discussion of Findings}

Concerning factors influencing parental expectations, the findings of this study were contrary to earlier literature that parental level of education influences their expectations of their children as reported by [3]. Also, contrary findings were revealed about the relationship between parental expectations and academic outcomes of young children $[5,10,15]$.

However the descriptive analysis showed that parents were more willing to assist their children in their homework or assignments as reported in earlier studies $[28,32]$. This study did not support earlier literature which reported that the type of disability influences parental expectations [21]. This study has however revealed some parental expectations about the education of children with special needs such as teachers encouraging children with special needs, extra support from teachers, high expectations by teachers for children with special needs, well-structured learning environments, teachers 
appreciating the individuality of the one with special needs, and teachers showing caring attitudes towards individuals with special needs. Others included teachers contacting parents when the need arose, parent-teacher conferences, and assisting children to develop self-esteem.

The findings of this study concerning parental involvement and its impact on the learning outcomes of students' with special needs support earlier literature that parental involvement leads to effective implementation of inclusive education [1,30]. Thus, parental involvement more than their expectations leads to improved learning outcomes for children with special needs and disabilities. These findings are more relevant in this era of inclusive education since the placement either in special or regular school is not the most determining factor rather parental involvement whether in special or regular schools.

\section{Conclusions}

Parents of children with special educational needs and disabilities have several expectations to be met by the school and teachers. Though evidence from the data gathered did not show any significant relationship between parents' expectations and their involvement, as well as the learning outcomes of children with special needs, their expectations combined with their involvement to predict improved learning outcomes for children with special educational needs and disabilities. Parental involvement was the single most important predictor of learning outcomes of children with special educational needs and disabilities. Though there were barriers to parental involvement, these barriers did not affect their involvement much. Therefore, there should be improved opportunities for parents to be involved in the education of their children with special educational needs to improve the learning outcomes of these learners.

\section{Recommendations}

Based on the findings of this study the following recommendations are made:

1. Schools and teachers should as much as possible involve parents of children with special educational needs and disabilities for enhanced learning outcomes for such children.

2. Children with special needs should be included in the regular school since the type of school does not really matter in the learning outcomes of children with special needs, however, in the regular schools they may learn other important skills.

3. Efforts should be made to eliminate barriers to parental involvement in order to improve learning outcomes of learners with special needs.

\section{REFERENCES}

[1] Afolabi, O. E., "Parents' Involvement in Inclusive Education: An Empirical Test for the Psycho-Educational Development of Learners with Special Education Needs (SENs)," International Journal of Educational Administration and Policy Studies, vol. 6, no.10, pp. 196-208, 2014.

[2] Assembly, UN General. "Universal declaration of human rights." UN General Assembly, vol. 302, no. 2, pp. 14-25, 1948.

[3] Banks, J., Maître, B., McCoy, S., \& Watson, D., "Parental Educational Expectations of Children with Disabilities," Economic and Social Research Institute, vol. 5, no. 21, pp. $1-87,2016$.

[4] Bariroh, S., "The Influence of Parents' Involvement on Children with Special Needs' Motivation and Learning Achievement," International Education Studies, vol. 11, no. 4, pp. 96-114, 2018.

[5] Benner, A. D., \& Mistry, R. S., "Congruence of mother and teacher educational expectations and low-income youth's academic competence," Journal of Educational Psychology, vol. 99, no. 1, pp.140, 2007.

[6] Bouck, E. C., "Secondary students with moderate/severe intellectual disability: considerations of curriculum and post-school outcomes from the National Longitudinal Transition Study-2," Journal of Intellectual Disability Research, vol. 56, no. 12, pp. 1175-86, 2012.

[7] Buchori, M., "Pendidikan Gagal Tanpa Partisipasi Orang Tua," Basis: Menembus Fakta, vol. 55, no. 7, pp. 13, 2006.

[8] Check, J., \& Schutt, R. K., "Teacher research and action research," Research methods in education, pp. 255-271, 2012.

[9] Clough, P., \& Nutbrown, C., "Special educational needs and inclusion: multiple perspectives of preschool educators in the UK," Journal of Early Childhood Research, vol. 2, no. 2, pp. 191-211, 2004.

[10] Cohen, L., Manion, L., \& Morrison, K., "Research methods in education," ( $8^{\text {th }}$ ed.). London, Routledge, 2018.

[11] Cosgrove, J., C. McKeown, J. Travers, Z. Lysaght, O. Ní Bhroin, \& P. Archer, "Educational Experiences and Outcomes for Children with Special Educational Needs, A Secondary Analysis of Data from the Growing Up in Ireland Study. Trim: NCSE Research Report, no. 15, pp. 48, 2014.

[12] Creswel, J. W., "Educational research: Planning, Conducting, and Evaluating Quantitative and Qualitative Research," Boston, Pearson Education, Inc., 2012.

[13] Davis-Kean, P. E., "The influence of parent education and family income on child achievement: the indirect role of parental expectations and the home environment," Journal of family psychology, vol. 19, no. 2, pp. 294, 2005.

[14] Dusek, G. A., Yurova, Y. V., \& Ruppel, C. P., "Using social media and targeted snowball sampling to survey a hard-to-reach population: A case study," International Journal of doctoral studies, vol.10, no. 1, pp. 279-299, 2015. 
[15] Fan, X., \& Chen, M., "Parental involvement and students' academic achievement: A meta-analysis," Educational Psychology Review," vol. 13, no. 1, pp. 1-22, 2001.

[16] Fish, W. W., "Perceptions of parents of students with autism towards the IEP meeting: A case study of one family support group chapter," Education, vol. 127, no. 1, pp. 56-68, 2006.

[17] Goodman, A., \& Gregg, P. (Eds.), "Poorer children's educational attainment: How important are attitudes and behavior" York: Joseph Rowntree Foundation, pp. 76-92, 2010.

[18] Guo, X., Guo, L., He, S., Liu, C., \& Luo, L., "Mothers' filial piety and children's academic achievement: the indirect effect via mother-child discrepancy in perceived parental expectations. Educational Psychology," vol. 40, no. 10, pp. 1230-1248, 2020.

[19] Hoover-Dempsey, Kathleen V., Joan, M. T. Walker, Howard M. Sandler, Darlene Whetsel, Christa L. Green, Andrew S. Wilkins, and Kristen Closson. "Why do parents become involved? Research findings and implications," The elementary school journal, vol. 106, no. 2, pp. 105-130, 2005.

[20] Humphrey, N., Wigelsworth, M., Barlow, A., \& Squires, G., "The role of school and individual differences in the academic attainment of learners with special educational needs and disabilities: A multi-level analysis," International Journal of Inclusive Education, vol. 17. no. 9, pp. 909-931, 2013.

[21] Jacobs, J. E., "Influence of gender stereotypes on parent and child mathematics attitudes," Journal of Educational Psychology, vol. 83, no. 4, pp. 518-27, 1991.

[22] Kuracki, Kamil., "Satisfaction with the support received by parents of children with disabilities and the diversity of parental behaviour towards the child," Interdisciplinary Context of Special Pedagogy, vol. 26, no. 1, pp. 191-215, 2019.

[23] Kuracki, K., and A. Dłużniewska, "Emotional and social competences and reading practice of Polish adolescent students with dyslexia and without dyslexia." In Edulearn 18. 10th International Conference on Education and New Learning Technology (Palma, 2nd-4th of July, 2018): conference proceedings, pp. 5072-5079. IATED Academy, 2018.

[24] Logsdon, A., "The important role of parents in special education," Verywellfamily, pp. 1-7, 2021. Retrieved online on 03/15,2021 from https://www.verywellfamily.co $\mathrm{m} /$ parenta;-importance-special-education
[25] Mitchell, D., "What Really Works in Special and Inclusive Education: Using evidence based teaching strategies," London: Routledge, 2008.

[26] Newman, L., "Family Involvement in the Educational Development of Youth with Disabilities, A Special Topic Report of Findings from the National Longitudinal Transition Study-2 (NLTS2)." Menlo Park, CA: Office of Special Education Programmes U.S. Department of Education by SRI International, 2005.

[27] Pearce, Richard R. "Effects of cultural and social structural factors on the achievement of White and Chinese American students at school transition points." American Educational Research Journal, vol. 43, no. 1, pp. 75-101, 2006.

[28] Roth, T., \& Salikutluk, Z., "Attitudes and expectations: do attitudes towards education mediate the relationship between social networks and parental expectations?" British Journal of Sociology of Education, vol. 33, no. 5, pp. 701-722, 2012

[29] Russell, F., "The expectations of parents of disabled children. British Journal of Special Education," vol. 30, no. 3, pp. 144-149, 2003.

[30] Spann, S. J., Kohler, F. W., \& Soenksen, D., "Examining parents' involvement in and perceptions of special education services: An interview with families in a parent support group," Focus on Autism and other Developmental Disabilities," vol. 18, no. 4, pp. 228-237, 2003.

[31] Spera, C., “Adolescents' perceptions of parental goals, practices, and styles in relation to their motivation and achievement," The Journal of Early Adolescence, vol. 26, no. 4, pp. 456-490, 2006.

[32] Stevenson, H. W., C. Chen, \& D. H. Uttal, "Beliefs and achievement: A study of Black, White, and Hispanic children," Child Development Special Issue: Minority Children, Vol. 61, pp. 508-23, 1990.

[33] Stoner, J. B., Bock, S. J., Thompson, J. R., Angell, M. E., Heyl, B. S., \& Crowley, E. P., "Welcome to our world: Parent perceptions of interactions between parents of young children with ASD and education professionals," Focus on Autism and Other Developmental Disabilities, vol. 20, no. 1, 39-51, 2005.

[34] Watson, D., J. Banks \& S. Lyons, "Educational and Employment Experiences of People with a Disability in Ireland: An Analysis of the National Disability Survey," Research Series, no. 41, 2015.

[35] Yamamoto, Y., \& Holloway, S. D., "Parental expectations and children's academic performance in sociocultural context," Educational Psychology Review, vol. 22, no. 3, pp. 189-214, 2010. 